\title{
Urotensin receptor in GtoPdb v.2021.3
}

Anthony P. Davenport ${ }^{1}$, Stephen A. Douglas ${ }^{2}$, Alain Fournier ${ }^{3}$, Adel Giaid ${ }^{4}$, Henry Krum ${ }^{5}$, David G. Lambert $^{6}$, Jérôme Leprince ${ }^{7}$, Margaret R. MacLean ${ }^{8}$, Eliot H. Ohlstein ${ }^{9}$, Walter G. Thomas ${ }^{10}$, Hervé Tostivint $^{11}$, David Vaudry ${ }^{7}$, Hubert Vaudry ${ }^{7}$ and David J. Webb ${ }^{12}$

1. University of Cambridge, UK

2. Wyeth Pharmaceuticals, USA

3. Université du Québec, Canada

4. McGill University, Canada

5. Monash University, Australia

6. University of Leicester, UK

7. Normandy University, France

8. University of Glasgow, UK

9. Drexel University, USA

10. University of Queensland, Australia

11. Muséum National d'Histoire Naturelle, France

12. University of Edinburgh, UK

\begin{abstract}
The urotensin-II (U-II) receptor (UT, nomenclature as agreed by the NC-IUPHAR Subcommittee on the Urotensin receptor $[26,36,93])$ is activated by the endogenous dodecapeptide urotensinII, originally isolated from the urophysis, the endocrine organ of the caudal neurosecretory system of teleost fish [7, 92]. Several structural forms of U-II exist in fish and amphibians [93]. The goby orthologue was used to identify U-II as the cognate ligand for the predicted receptor encoded by the rat gene gpr14 [2, 20, 63, 69, 72]. Human urotensin-II, an 11-amino-acid peptide [20], retains the cyclohexapeptide sequence of goby U-II that is thought to be important in ligand binding [61, 53, 10]. This sequence is also conserved in the deduced amino-acid sequence of rat urotensin-II (14 aminoacids) and mouse urotensin-II (14 amino-acids), although the N-terminal is more divergent from the human sequence [19]. A second endogenous ligand for the UT has been discovered in rat [86]. This is the urotensin II-related peptide, an octapeptide that is derived from a different gene, but shares the $\mathrm{C}$-terminal sequence (CFWKYCV) common to U-II from other species. Identical sequences to rat urotensin II-related peptide are predicted for the mature mouse and human peptides [32]. UT exhibits relatively high sequence identity with somatostatin, opioid and galanin receptors [93].
\end{abstract}

\section{Contents}

This is a citation summary for Urotensin receptor in the Guide to Pharmacology database (GtoPdb). It exists purely as an adjunct to the database to facilitate the recognition of citations to and from the database by citation analyzers. Readers will almost certainly want to visit the relevant sections of the database which are given here under database links.

GtoPdb is an expert-driven guide to pharmacological targets and the substances that act on them. GtoPdb is a reference work which is most usefully represented as an on-line database. As in any publication this work should be appropriately cited, and the papers it cites should also be recognized. This document provides a citation for the relevant parts of the database, and also provides a reference list for the research cited by those parts. For further details see [11].

Please note that the database version for the citations given in GtoPdb are to the most recent preceding version in which the family or its subfamilies and targets were substantially changed. The links below are to the current version. If you need to consult the cited version, rather than the most recent version, please contact the GtoPdb curators.

\section{Database links}


Urotensin receptor

https://www.guidetopharmacology.org/GRAC/FamilyDisplayForward?familyId=65

Introduction to Urotensin receptor

https://www.guidetopharmacology.org/GRAC/FamilyIntroductionForward?familyId=65

Receptors

UT receptor

https://www.guidetopharmacology.org/GRAC/ObjectDisplayForward?objectId=365

\section{References}

1. Affolter JT, Newby DE, Wilkinson IB, Winter MJ, Balment RJ and Webb DJ. (2002) No effect on central or peripheral blood pressure of systemic urotensin II infusion in humans. Br J Clin Pharmacol 54: 617-21 [PMID:12492609]

2. Ames RS, Sarau HM, Chambers JK, Willette RN, Aiyar NV, Romanic AM, Louden CS, Foley JJ, Sauermelch CF and Coatney RW et al.. (1999) Human urotensin-II is a potent vasoconstrictor and agonist for the orphan receptor GPR14. Nature 401: 282-6 [PMID:10499587]

3. Bandholtz S, Erdmann S, von Hacht JL, Exner S, Krause G, Kleinau G and Grötzinger C. (2016) Urolinin: The First Linear Peptidic Urotensin-II Receptor Agonist. J Med Chem 59: 10100-10112 [PMID:27791374]

4. Behm DJ, Harrison SM, Ao Z, Maniscalco K, Pickering SJ, Grau EV, Woods TN, Coatney RW, Doe CP and Willette RN et al.. (2003) Deletion of the UT receptor gene results in the selective loss of urotensin-II contractile activity in aortae isolated from UT receptor knockout mice. $\mathrm{Br} \mathrm{J}$ Pharmacol 139: 464-72 [PMID:12770952]

5. Behm DJ, Herold CL, Ohlstein EH, Knight SD, Dhanak D and Douglas SA. (2002) Pharmacological characterization of SB-710411 (Cpa-c[D-Cys-Pal-D-Trp-Lys-Val-Cys]-Cpaamide), a novel peptidic urotensin-II receptor antagonist. Br J Pharmacol 137: 449-58 [PMID:12359626]

6. Bern HA and Lederis K. (1969) A reference preparation for the study of active substances in the caudal neurosecretory system of teleosts. J Endocrinol 45: Suppl:xi-xii [PMID:5347394]

7. Bern HA, Pearson D, Larson BA and Nishioka RS. (1985) Neurohormones from fish tails: the caudal neurosecretory system. I: "Urophysiology" and the caudal neurosecretory system of fishes. Recent Prog Horm Res 41: 533-552 [PMID:2864726]

8. Birker-Robaczewska M, Boukhadra C, Studer R, Mueller C, Binkert C and Nayler O. (2003) The expression of urotensin II receptor (U2R) is up-regulated by interferon-gamma. J Recept Signal Transduct Res 23: 289-305 [PMID:14753294]

9. Boucard AA, Sauvé SS, Guillemette G, Escher E and Leduc R. (2003) Photolabelling the rat urotensin II/GPR14 receptor identifies a ligand-binding site in the fourth transmembrane domain. Biochem J 370: 829-38 [PMID:12495432]

10. Brkovic A, Hattenberger A, Kostenis E, Klabunde T, Flohr S, Kurz M, Bourgault S and Fournier A. (2003) Functional and binding characterizations of urotensin II-related peptides in human and rat urotensin II-receptor assay. J Pharmacol Exp Ther 306: 1200-9 [PMID:12807997]

11. Buneman P, Christie G, Davies JA, Dimitrellou R, Harding SD, Pawson AJ, Sharman JL and Wu Y. (2020) Why data citation isn't working, and what to do about it Database 2020 [PMID:32367113]

12. Böhm F and Pernow J. (2002) Urotensin II evokes potent vasoconstriction in humans in vivo. $\mathrm{Br} J$ Pharmacol 135: 25-7 [PMID:11786476]

13. Camarda V, Guerrini R, Kostenis E, Rizzi A, Calò G, Hattenberger A, Zucchini M, Salvadori S and Regoli D. (2002) A new ligand for the urotensin II receptor. Br J Pharmacol 137: 311-4 [PMID:12237249]

14. Chatenet D, Dubessy C, Boularan C, Scalbert E, Pfeiffer B, Renard P, Lihrmann I, Pacaud P, Tonon MC and Vaudry H et al.. (2006) Structure-activity relationships of a novel series of urotensin II analogues: identification of a urotensin II antagonist. J Med Chem 49: 7234-8 [PMID:17125276]

15. Clark SD, Nothacker HP, Blaha CD, Tyler CJ, Duangdao DM, Grupke SL, Helton DR, Leonard CS and Civelli O. (2005) Urotensin II acts as a modulator of mesopontine cholinergic neurons. Brain Res 1059: 139-48 [PMID:16183039]

16. Clozel M, Binkert C, Birker-Robaczewska M, Boukhadra C, Ding SS, Fischli W, Hess P, Mathys B, Morrison K and Müller C et al.. (2004) Pharmacology of the urotensin-II receptor antagonist palosuran (ACT-058362; 1-[2-(4-benzyl-4-hydroxy-piperidin-1-yl)-ethyl]-3-(2-methyl-quinolin-4yl)-urea sulfate salt): first demonstration of a pathophysiological role of the urotensin System. $J$ Pharmacol Exp Ther 311: 204-12 [PMID:15146030]

17. Conlon JM, Tostivint H and Vaudry H. (1997) Somatostatin- and urotensin II-related peptides: molecular diversity and evolutionary perspectives. Regul Pept 69: 95-103 [PMID:9178352]

18. Conlon JM, Yano K, Waugh D and Hazon N. (1996) Distribution and molecular forms of urotensin II and its role in cardiovascular regulation in vertebrates. J Exp Zool 275: 226-238 
[PMID:8676097]

19. Coulouarn Y, Jégou S, Tostivint H, Vaudry H and Lihrmann I. (1999) Cloning, sequence analysis and tissue distribution of the mouse and rat urotensin II precursors. FEBS Lett 457: 28-32 [PMID:10486557]

20. Coulouarn Y, Lihrmann I, Jegou S, Anouar Y, Tostivint H, Beauvillain JC, Conlon JM, Bern HA and Vaudry H. (1998) Cloning of the cDNA encoding the urotensin II precursor in frog and human reveals intense expression of the urotensin II gene in motoneurons of the spinal cord. Proc Natl Acad Sci USA 95: 15803-8 [PMID:9861051]

21. Coy DH, Rossowski WJ, Cheng BL and Taylor JE. (2002) Structural requirements at the Nterminus of urotensin II octapeptides. Peptides 23: 2259-64 [PMID:12535707]

22. Croston GE, Olsson R, Currier EA, Burstein ES, Weiner D, Nash N, Severance D, Allenmark SG, Thunberg L and Ma JN et al.. (2002) Discovery of the first nonpeptide agonist of the GPR14/urotensin-II receptor: 3-(4-chlorophenyl)-3-(2- (dimethylamino)ethyl)isochroman-1-one (AC-7954). J Med Chem 45: 4950-3 [PMID:12408704]

23. Dhanak D, Neeb MJ and Douglas SA. (2003) Urotensin-II receptor modulators. Ann Rep Med Chem 38: 99-110

24. Diallo M, Jarry M, Desrues L, Castel H, Chatenet D, Leprince J, Vaudry H, Tonon MC and Gandolfo P. (2008) [Orn5]URP acts as a pure antagonist of urotensinergic receptors in rat cortical astrocytes. Peptides 29: 813-9 [PMID:18082287]

25. Doan ND, Nguyen TT, Létourneau M, Turcotte K, Fournier A and Chatenet D. (2012) Biochemical and pharmacological characterization of nuclear urotensin-II binding sites in rat heart. Br J Pharmacol 166: 243-57 [PMID:22044114]

26. Douglas SA Ohlstein EH. (2000) Urotensin receptors. In The IUPHAR Receptor Compendium of Receptor Characterization and Classification. Edited by Girdlestone D: IUPHAR Media Ltd: 365372

27. Douglas SA, Behm DJ, Aiyar NV, Naselsky D, Disa J, Brooks DP, Ohlstein EH, Gleason JG, Sarau HM and Foley JJ et al.. (2005) Nonpeptidic urotensin-II receptor antagonists I: in vitro pharmacological characterization of SB-706375. Br J Pharmacol 145: 620-35 [PMID:15852036]

28. Douglas SA, Dhanak D and Johns DG. (2004) From 'gills to pills': urotensin-II as a regulator of mammalian cardiorenal function. Trends Pharmacol Sci 25: 76-85 [PMID:15102493]

29. Douglas SA and Gupta D. (2003) Endoscopic assisted external approach anterior ethmoidal artery ligation for the management of epistaxis. J Laryngol Otol 117: 132-3 [PMID:12625888]

30. Douglas SA, Naselsky D, Ao Z, Disa J, Herold CL, Lynch F and Aiyar NV. (2004) Identification and pharmacological characterization of native, functional human urotensin-II receptors in rhabdomyosarcoma cell lines. Br J Pharmacol 142: 921-32 [PMID:15210573]

31. Douglas SA, Sulpizio AC, Piercy V, Sarau HM, Ames RS, Aiyar NV, Ohlstein EH and Willette RN. (2000) Differential vasoconstrictor activity of human urotensin-II in vascular tissue isolated from the rat, mouse, dog, pig, marmoset and cynomolgus monkey. Br J Pharmacol 131: 1262-74 [PMID:11090097]

32. Dubessy C, Cartier D, Lectez B, Bucharles C, Chartrel N, Montero-Hadjadje M, Bizet P, Chatenet D, Tostivint H and Scalbert E et al.. (2008) Characterization of urotensin II, distribution of urotensin II, urotensin II-related peptide and UT receptor mRNAs in mouse: evidence of urotensin II at the neuromuscular junction. J Neurochem 107: 361-74 [PMID:18710417]

33. Elshourbagy NA, Douglas SA, Shabon U, Harrison S, Duddy G, Sechler JL, Ao Z, Maleeff BE, Naselsky D and Disa J et al.. (2002) Molecular and pharmacological characterization of genes encoding urotensin-II peptides and their cognate G-protein-coupled receptors from the mouse and monkey. Br J Pharmacol 136: 9-22 [PMID:11976263]

34. Filipeanu CM, Brailoiu E, Le Dun S and Dun NJ. (2002) Urotensin-II regulates intracellular calcium in dissociated rat spinal cord neurons. J Neurochem 83: 879-84 [PMID:12421360]

35. Flohr S, Kurz M, Kostenis E, Brkovich A, Fournier A and Klabunde T. (2002) Identification of nonpeptidic urotensin II receptor antagonists by virtual screening based on a pharmacophore model derived from structure-activity relationships and nuclear magnetic resonance studies on urotensin II. J Med Chem 45: 1799-805 [PMID:11960491]

36. Foord SM, Bonner TI, Neubig RR, Rosser EM, Pin JP, Davenport AP, Spedding M and Harmar AJ. (2005) International Union of Pharmacology. XLVI. G protein-coupled receptor list. Pharmacol Rev 57: 279-88 [PMID:15914470]

37. Gibson A. (1987) Complex effects of Gillichthys urotensin II on rat aortic strips. BrJ Pharmacol 91: 205-12 [PMID:2885055]

38. Gibson A, Bern HA, Ginsburg M and Botting JH. (1984) Neuropeptide-induced contraction and relaxation of the mouse anococcygeus muscle. Proc Natl Acad Sci USA 81: 625-9 [PMID:6582516]

39. Gibson A, Conyers S and Bern HA. (1988) The influence of urotensin II on calcium flux in rat aorta. J Pharm Pharmacol 40: 893-5 [PMID:2907588]

40. Gibson A, Wallace P and Bern HA. (1986) Cardiovascular effects of urotensin II in anesthetized 
and pithed rats. Gen Comp Endocrinol 64: 435-9 [PMID:2879765]

41. Gilbert RE, Douglas SA and Krum H. (2004) Urotensin-II as a novel therapeutic target in the clinical management of cardiorenal disease. Curr Opin Investig Drugs 5: 276-82 [PMID:15083593]

42. Grieco P, Carotenuto A, Campiglia P, Zampelli E, Patacchini R, Maggi CA, Novellino E and Rovero P. (2002) A new, potent urotensin II receptor peptide agonist containing a Pen residue at the disulfide bridge. J Med Chem 45: 4391-4 [PMID:12238917]

43. Hasegawa K, Kobayashi Y and Kobayashi H. (1992) Vasodepressor effects of urotensin II in rats. Neuro Endocrinol Lett 14: 357-363

44. Herold CL, Behm DJ, Buckley PT, Foley JJ, Wixted WE, Sarau HM and Douglas SA. (2003) The neuromedin $\mathrm{B}$ receptor antagonist, BIM-23127, is a potent antagonist at human and rat urotensin-II receptors. Br J Pharmacol 139: 203-7 [PMID:12770925]

45. Herold CL, Behm DJ, Buckley PT, FoleyJJ, null and Douglas SA. (2002) The peptidic somatostatin analogs lanreotide, BIM-23127 and BIM 23042 are urotensin-II receptor ligands. Pharmacologist 44: $170-171$

46. Huitron-Resendiz S, Kristensen MP, Sánchez-Alavez M, Clark SD, Grupke SL, Tyler C, Suzuki C, Nothacker HP, Civelli O and Criado JR et al.. (2005) Urotensin II modulates rapid eye movement sleep through activation of brainstem cholinergic neurons. J Neurosci 25: 5465-74 [PMID:15944374]

47. Itoh H, Higuchi H, Hiraoka N, Ito M, Konishi T, Nakano T and Lederis K. (1991) Contraction of rat thoracic aorta strips by endothelin-1 in the absence of extracellular Ca2+. Br J Pharmacol 104: 847-52 [PMID:1810598]

48. Itoh H, Itoh Y, Rivier J and Lederis K. (1987) Contraction of major artery segments of rat by fish neuropeptide urotensin II. Am J Physiol 252: R361-6 [PMID:3812773]

49. Itoh $\mathrm{H}$, McMaster D and Lederis K. (1988) Functional receptors for fish neuropeptide urotensin II in major rat arteries. Eur J Pharmacol 149: 61-6 [PMID:3396626]

50. Jin J, An M, Sapienza A, Aiyar N, Naselsky D, Sarau HM, Foley JJ, Salyers KL, Knight SD and Keenan RM et al.. (2008) Urotensin-II receptor antagonists: synthesis and SAR of N-cyclic azaalkyl benzamides. Bioorg Med Chem Lett 18: 3950-4 [PMID:18573659]

51. Jin J, Dhanak D, Knight SD, Widdowson K, Aiyar N, Naselsky D, Sarau HM, Foley JJ, Schmidt DB and Bennett CD et al.. (2005) Aminoalkoxybenzyl pyrrolidines as novel human urotensin-II receptor antagonists. Bioorg Med Chem Lett 15: 3229-32 [PMID:15936190]

52. Kelsall CJ and Balment RJ. (1998) Native urotensins influence cortisol secretion and plasma cortisol concentration in the euryhaline flounder, platichthys flesus. Gen Comp Endocrinol 112: 210-9 [PMID:9784304]

53. Kinney WA, Almond Jr HR, Qi J, Smith CE, Santulli RJ, de Garavilla L, Andrade-Gordon P, Cho DS, Everson AM and Feinstein MA et al.. (2002) Structure-function analysis of urotensin II and its use in the construction of a ligand-receptor working model. Angew Chem Int Ed Engl 41: 2940-4 [PMID:12203418]

54. Kobayashi Y, Lederis K, Rivier J, Ko D, McMaster D and Poulin P. (1986) Radioimmunoassays for fish tail neuropeptides: II. Development of a specific and sensitive assay for and the occurrence of immunoreactive urotensin II in the central nervous system and blood of Catostomus commersoni. J Pharmacol Methods 15: 321-33 [PMID:3724202]

55. Labarrère P, Chatenet D, Leprince J, Marionneau C, Loirand G, Tonon MC, Dubessy C, Scalbert E, Pfeiffer B and Renard P et al.. (2003) Structure-activity relationships of human urotensin II and related analogues on rat aortic ring contraction. J Enzyme Inhib Med Chem 18: 77-88 [PMID:12943190]

56. Lawson EC, Luci DK, Ghosh S, Kinney WA, Reynolds CH, Qi J, Smith CE, Wang Y, Minor LK and Haertlein BJ et al.. (2009) Nonpeptide urotensin-II receptor antagonists: a new ligand class based on piperazino-phthalimide and piperazino-isoindolinone subunits. J Med Chem 52: 743245 [PMID:19731961]

57. Lederis K. (1984) The fish urotensins: hypophyseal and peripheral actions in fishes and mammals. In Frontiers in neuroendocrinology 8: Edited by Martin L, Ganong WF: Raven Press: 247-263

58. Lehmann F, Currier EA, Clemons B, Hansen LK, Olsson R, Hacksell U and Luthman K. (2009) Novel and potent small-molecule urotensin II receptor agonists. Bioorg Med Chem 17: 4657-65 [PMID:19481466]

59. Lehmann F, Currier EA, Olsson R, Hacksell U and Luthman K. (2005) Isochromanone-based urotensin-II receptor agonists. Bioorg Med Chem 13: 3057-68 [PMID:15781415]

60. Lehmann F, Lake L, Currier EA, Olsson R, Hacksell U and Luthman K. (2007) Design, parallel synthesis and SAR of novel urotensin II receptor agonists. Eur J Med Chem 42: 276-85 [PMID:17112638]

61. Leprince J, Chatenet D, Dubessy C, Fournier A, Pfeiffer B, Scalbert E, Renard P, Pacaud P, Oulyadi H and Ségalas-Milazzo I et al.. (2008) Structure-activity relationships of urotensin II and URP. Peptides 29: 658-73 [PMID:17931747] 
62. Lim M, Honisett S, Sparkes CD, Komesaroff P, Kompa A and Krum H. (2004) Differential effect of urotensin II on vascular tone in normal subjects and patients with chronic heart failure. Circulation 109: 1212-4 [PMID:15007012]

63. Liu Q, Pong SS, Zeng Z, Zhang Q, Howard AD, Williams Jr DL, Davidoff M, Wang R, Austin CP and McDonald TP et al.. (1999) Identification of urotensin II as the endogenous ligand for the orphan G-protein-coupled receptor GPR14. Biochem Biophys Res Commun 266: 174-8 [PMID:10581185]

64. Loretz CA, Howard ME and Siegel AJ. (1985) Ion transport in goby intestine: cellular mechanism of urotensin II stimulation. Am J Physiol 249: G284-93 [PMID:2411149]

65. Maguire JJ and Davenport AP. (2002) Is urotensin-II the new endothelin? BrJ Pharmacol 137: 579-588 [PMID:12381671]

66. Maguire JJ, Kuc RE and Davenport AP. (2000) Orphan-receptor ligand human urotensin II: receptor localization in human tissues and comparison of vasoconstrictor responses with endothelin-1. Br J Pharmacol 131: 441-6 [PMID:11015293]

67. Marchese A, Heiber M, Nguyen T, Heng HH, Saldivia VR, Cheng R, Murphy PM, Tsui LC, Shi X and Gregor P et al.. (1995) Cloning and chromosomal mapping of three novel genes, GPR9, GPR10, and GPR14, encoding receptors related to interleukin 8, neuropeptide Y, and somatostatin receptors. Genomics 29: 335-44 [PMID:8666380]

68. Matsushita M, Shichiri M, Fukai N, Ozawa N, Yoshimoto T, Takasu N and Hirata Y. (2003) Urotensin II is an autocrine/paracrine growth factor for the porcine renal epithelial cell line, LLCPK1. Endocrinology 144: 1825-31 [PMID:12697688]

69. Mori M, Sugo T, Abe M, Shimomura Y, Kurihara M, Kitada C, Kikuchi K, Shintani Y, Kurokawa T and Onda $\mathrm{H}$ et al.. (1999) Urotensin II is the endogenous ligand of a G-protein-coupled orphan receptor, SENR (GPR14). Biochem Biophys Res Commun 265: 123-9 [PMID:10548501]

70. Muramatsu I, Fujiwara M, Hidaka H and Akutagawa H. (1979) Pharmacological analysis of urotensin-induced contraction and relaxation in isolated rabbit aortas. Gunma Symp Endocrinol 16: $39-47$

71. Nishi M, Yonesu K, Tagawa H, Kato M, Marumoto S and Nagayama T. (2019) A Novel and Highly Potent Urotensin II Receptor Antagonist Inhibits Urotensin II-Induced Pressure Response in Mice. J Cardiovasc Pharmacol 73: 15-21 [PMID:30608334]

72. Nothacker HP, Wang Z, McNeill AM, Saito Y, Merten S, O'Dowd B, Duckles SP and Civelli O. (1999) Identification of the natural ligand of an orphan G-protein-coupled receptor involved in the regulation of vasoconstriction. Nat Cell Biol 1: 383-5 [PMID:10559967]

73. Ohsako S, Ishida I, Ichikawa T and Deguchi T. (1986) Cloning and sequence analysis of cDNAs encoding precursors of urotensin II-alpha and -gamma. J Neurosci 6: 2730-5 [PMID:2427672]

74. Ozoux ML, Briand V, Pelat M, Barbe F, Schaeffer P, Beauverger P, Poirier B, Guillon JM, Petit F and Altenburger JM et al.. (2020) Potential Therapeutic Value of Urotensin II Receptor Antagonist in Chronic Kidney Disease and Associated Comorbidities. J Pharmacol Exp Ther 374: 24-37 [PMID:32332113]

75. Patacchini R, Santicioli P, Giuliani S, Grieco P, Novellino E, Rovero P and Maggi CA. (2003) Urantide, an ultrapotent urotensin II antagonist peptide in the rat aorta. BrJ Pharmacol 140: 1155-1158 [PMID:14645137]

76. Pearson D, Shively JE, Clark BR, Geschwind II, Barkley M, Nishioka RS and Bern HA. (1980) Urotensin II: a somatostatin-like peptide in the caudal neurosecretory system of fishes. Proc Natl Acad Sci USA 77: 5021-4 [PMID:6107911]

77. Rakowski E, Hassan GS, Dhanak D, Ohlstein EH, Douglas SA and Giaid A. (2005) A role for urotensin II in restenosis following balloon angioplasty: use of a selective UT receptor blocker. $J$ Mol Cell Cardiol 39: 785-91 [PMID:16171813]

78. Rossowski WJ, Cheng BL, Taylor JE, Datta R and Coy DH. (2002) Human urotensin II-induced aorta ring contractions are mediated by protein kinase $\mathrm{C}$, tyrosine kinases and Rho-kinase: inhibition by somatostatin receptor antagonists. Eur J Pharmacol 438: 159-70 [PMID:11909607]

79. Russell FD, Molenaar P and O'Brien DM. (2001) Cardiostimulant effects of urotensin-II in human heart in vitro. Br J Pharmacol 132: 5-9 [PMID:11156554]

80. Saetrum Opgaard O, Nothacker H, Ehlert FJ and Krause DN. (2000) Human urotensin II mediates vasoconstriction via an increase in inositol phosphates. Eur J Pharmacol 406: 265-71 [PMID:11020490]

81. Sauzeau V, Le Mellionnec E, Bertoglio J, Scalbert E, Pacaud P and Loirand G. (2001) Human urotensin II-induced contraction and arterial smooth muscle cell proliferation are mediated by RhoA and Rho-kinase. Circ Res 88: 1102-4 [PMID:11397774]

82. Sheridan MA and Bern HA. (1986) Both somatostatin and the caudal neuropeptide, urotensin II, stimulate lipid mobilization from coho salmon liver incubated in vitro. Regul Pept 14: 333-44 [PMID:2428079]

83. Silvestre RA, Rodríguez-Gallardo J, Egido EM and Marco J. (2001) Effect of leptin on insulin, glugacon and somatostatin secretion in the perfused rat pancreas. Horm Metab Res 33: 207-12 [PMID:11383923] 
84. Stadel JM, Wilson S and Bergsma DJ. (1997) Orphan G protein-coupled receptors: a neglected opportunity for pioneer drug discovery. Trends Pharmacol Sci 18: 430-7 [PMID:9426471]

85. Stirrat A, Gallagher M, Douglas SA, Ohlstein EH, Berry C, Kirk A, Richardson M and MacLean MR. (2001) Potent vasodilator responses to human urotensin-II in human pulmonary and abdominal resistance arteries. Am J Physiol Heart Circ Physiol 280: H925-8 [PMID:11158995]

86. Sugo T and Mori M. (2008) Another ligand fishing for G protein-coupled receptor 14. Discovery of urotensin II-related peptide in the rat brain. Peptides 29: 809-12 [PMID:17628210]

87. Sugo T, Murakami Y, Shimomura Y, Harada M, Abe M, Ishibashi Y, Kitada C, Miyajima N, Suzuki $\mathrm{N}$ and Mori $\mathrm{M}$ et al.. (2003) Identification of urotensin II-related peptide as the urotensin IIimmunoreactive molecule in the rat brain. Biochem Biophys Res Commun 310: 860-8 [PMID:14550283]

88. Tal M, Ammar DA, Karpuj M, Krizhanovsky V, Naim M and Thompson DA. (1995) A novel putative neuropeptide receptor expressed in neural tissue, including sensory epithelia. Biochem Biophys Res Commun 209: 752-9 [PMID:7733947]

89. Tamura K, Okazaki M, Tamura M, Isozumi K, Tasaki H and Nakashima Y. (2003) Urotensin IIinduced activation of extracellular signal-regulated kinase in cultured vascular smooth muscle cells: involvement of cell adhesion-mediated integrin signaling. Life Sci 72: 1049-60 [PMID:12495783]

90. Tandon R, Soni A, Singh RK, Sodhi R, Seth MK, Sinha S, Sahdev S, Dhage G, Das B and Dastidar SG et al.. (2020) Identification of novel Urotensin-II receptor antagonists with potent inhibition of U-II induced pressor response in mice. Eur J Pharmacol 886: 173391 [PMID:32745605]

91. Tzanidis A, Hannan RD, Thomas WG, Onan D, Autelitano DJ, See F, Kelly DJ, Gilbert RE and Krum H. (2003) Direct actions of urotensin II on the heart: implications for cardiac fibrosis and hypertrophy. Circ Res 93: 246-53 [PMID:12842917]

92. Vaudry H, Do Rego JC, Le Mevel JC, Chatenet D, Tostivint H, Fournier A, Tonon MC, Pelletier G, Conlon JM and Leprince J. (2010) Urotensin II, from fish to human. Ann N Y Acad Sci 1200: 5366 [PMID:20633133]

93. Vaudry H, Leprince J, Chatenet D, Fournier A, Lambert DG, Le Mével JC, Ohlstein EH, Schwertani A, Tostivint H and Vaudry D. (2015) International Union of Basic and Clinical Pharmacology. XCII. Urotensin II, urotensin II-related peptide, and their receptor: from structure to function. Pharmacol Rev 67: 214-58 [PMID:25535277]

94. Watanabe T, Pakala R, Katagiri T and Benedict CR. (2001) Synergistic effect of urotensin II with mildly oxidized LDL on DNA synthesis in vascular smooth muscle cells. Circulation 104: 16-8 [PMID:11435331]

95. Wenyi Z, Suzuki S, Hirai M, Hinokio Y, Tanizawa Y, Matsutani A, Satoh J and Oka Y. (2003) Role of urotensin II gene in genetic susceptibility to Type 2 diabetes mellitus in Japanese subjects. Diabetologia 46: 972-6 [PMID:12830381]

96. Wilkinson IB, Affolter JT, de Haas SL, Pellegrini MP, Boyd J, Winter MJ, Balment RJ and Webb DJ. (2002) High plasma concentrations of human urotensin II do not alter local or systemic hemodynamics in man. Cardiovasc Res 53: 341-7 [PMID:11827684]

97. Yano K, Vaudry H and Conlon JM. (1994) Spasmogenic actions of frog urotensin II on the bladder and ileum of the frog, Rana catesbeiana. Gen Comp Endocrinol 96: 412-9 [PMID:7883148]

98. Ziltener P, Mueller C, Haenig B, Scherz MW and Nayler O. (2002) Urotensin II mediates ERK1/2 phosphorylation and proliferation in GPR14-transfected cell lines. J Recept Signal Transduct Res 22: 155-68 [PMID:12503613]

99. Zou Y, Nagai R and Yamazaki T. (2001) Urotensin II induces hypertrophic responses in cultured cardiomyocytes from neonatal rats. FEBS Lett 508: 57-60 [PMID:11707268] 